\title{
Relationship of Childhood Weight Status to Morbidity in Adults
}

\author{
SIDNEY ABRAHAM, GRETCHEN COLLINS, and MARIE NORDSIECK
}

\begin{abstract}
$A^{N}$
ASSOCIATION between adult obesity, cardiovascular renal disease, and diabetes has been demonstrated from life insurance data and from various prospective field studies $(1-3)$. However, the nature of this relationship has not been defined. Despite the evidence relating childhood obesity to adult obesity, little information is available on the role of childhood obesity in the morbidity or mortality of adults.

We investigated the relationship of childhood weight status to adult levels of selected physiological variables and to increased morbidity from cardiovascular renal disease and diabetes.

The study population was located in Hagerstown, Md., an area which has been followed as a population laboratory by the Public Health Service since the 1920's (4). We selected 1,963 white males who had attended elementary schools in Hagerstown between 1923 and 1928, who were in the age group 9-13 years at that time, and whose height and weight measurements were available. Childhood weight status was determined by using relative weight defined as the deviation of actual weight for given sex, age,
\end{abstract}

and height from average weight values, times 100 , obtained from the Baldwin-Wood height-weight tables (5).

\section{Adult Followup}

To locate the study population a systematic search was made between 1961 and 1963 of available records, which included the city directory, telephone

At the time this study was made, the authors were with the Heart Disease Program, Regional Medical Programs Service, Public Health Service. They were assisted by Miss Anne Alderman, a statistician. At present, Mr. Abraham is acting chief, Nutrition Statistics Branch, Division of Health Examination Statistics, National Center for Health Statistics; Miss Collins is assistant chief of the Demonstrations and Technical Services Branch, Nutrition Program, Center for Disease Control; Miss Nordsieck is a statistician in the National Institute of Allergy and Infectious Diseases. Tearsheet requests to Sidney Abraham, Room 8A-44, Parklawn Bldg., 5600 Fishers Lane, Rockville, Md. 20852. 
directory, selective service lists, and death certificates. From these sources, 1,691 of the 1,963 men were identified after a lapse of $30-40$ years. Table 1 shows the disposition of the subjects for followup.

A total of 717 persons were available for examination. The examinations, performed in the Washington County Health Department by two clinicians and two registered nurses, consisted of a medical history, physical examination, routine urinalysis, chest X-ray, standard 12-lead ECG, and fasting blood sugar (Folin-Wu technique). Serum cholesterol levels were determined according to the Bloor method and estimations of serum beta-lipoprotein according to the immunocrit method. (Units are in millimeters of beta-lipoprotein precipitate as measured in a standard length capillary tube.)

All laboratory tests were performed in the health department laboratory. Techniques for serum cholesterol and beta-lipoprotein determinations were standardized by the Heart Disease Control Program Laboratory, Communicable Disease Center, Atlanta, $\mathrm{Ga}$. Blood pressure determinations were made using a standard mercury sphygmomanometer, with first and fifth phase Korotkoff sounds taken as end points for systolic and diastolic blood pressures.

Adult relative weight status, determined for the
Table 1. Results of followup of 1,963 study subjects, Hagerstown, Md.

\begin{tabular}{|c|c|c|}
\hline Results & Number & Percent \\
\hline Total study population.....- & 1,963 & 100. 0 \\
\hline Located. & 1,506 & 76. 7 \\
\hline Interviewed & 902 & 45.9 \\
\hline $\begin{array}{l}\text { Examined, history, and } \\
\text { laboratory }\end{array}$ & & \\
\hline laboratory & 684 & 34.8 \\
\hline Examined and history & 33 & 1. 7 \\
\hline History only & 185 & 9.4 \\
\hline Not interviewed & 604 & 30.8 \\
\hline Refused $\ldots$ & 176 & 9. 0 \\
\hline Invalid & 14 & \\
\hline Out of country & 414 & 21. 1 \\
\hline Cannot locate & 272 & 13.9 \\
\hline Died & 185 & 9.4 \\
\hline
\end{tabular}

segment of the cohort examined during 1961-63, was defined as deviation of actual weight for given sex, age, and height (measured at time of examination) from average weights, times 100, obtained from the "1959 Build and Blood Pressure Study" $(6)$.

Both childhood and adult relative weight status were arbitrarily divided into the following four weight categories: below average weight, under 95 ; average weight, 95-104; moderately overweight, 105-119; and markedly overweight, 120 and more.

Table 2. Study subjects available and not available for followup, by childhood weight status

\begin{tabular}{|c|c|c|c|c|c|c|}
\hline \multirow{2}{*}{ Childhood weight } & \multicolumn{2}{|c|}{ Total } & \multicolumn{2}{|c|}{ Available } & \multicolumn{2}{|c|}{ Not available } \\
\hline & Number & Percent & Number & Percent & Number & Percent \\
\hline $\begin{array}{l}\text { Below average }(<95) \\
\text { Average }(95-104) \\
\text { Moderately overweight }(105-119) \\
\text { Markedly overweight (120 and more) }\end{array}$ & $\begin{array}{r}644 \\
958 \\
296 \\
65\end{array}$ & $\begin{array}{r}32.8 \\
48.8 \\
15.0 \\
3.3\end{array}$ & $\begin{array}{r}354 \\
533 \\
162 \\
38\end{array}$ & $\begin{array}{r}32.6 \\
49.0 \\
14.9 \\
3.6\end{array}$ & $\begin{array}{r}290 \\
425 \\
134 \\
27\end{array}$ & $\begin{array}{r}\text { 33. } 1 \\
48.5 \\
15.3 \\
3.0\end{array}$ \\
\hline - & 1,963 & 100.0 & 1,087 & 100.0 & 876 & 100.0 \\
\hline
\end{tabular}

Table 3. Weight status of selected males as school children and as adults

\begin{tabular}{|c|c|c|c|c|c|c|c|c|c|}
\hline \multirow{3}{*}{ Childhood weight } & \multirow{3}{*}{$\begin{array}{l}\text { Number } \\
\text { males }\end{array}$} & \multicolumn{8}{|c|}{ Adult weight } \\
\hline & & \multicolumn{2}{|c|}{$\begin{array}{l}\text { Below average } \\
(<95)\end{array}$} & \multicolumn{2}{|c|}{$\begin{array}{l}\text { Average } \\
(95-104)\end{array}$} & \multicolumn{2}{|c|}{$\begin{array}{l}\text { Moderately } \\
\text { overweight } \\
(105-119)\end{array}$} & \multicolumn{2}{|c|}{$\begin{array}{c}\text { Markedly } \\
\text { overweight } \\
\text { (120 and more) }\end{array}$} \\
\hline & & Number & Percent & Number & Percent & Number & Percent & Number & Percent \\
\hline $\begin{array}{l}\text { Below average }(<95) \\
\text { Average }(95-104) \\
\text { Moderately overweight }\end{array}$ & $\begin{array}{r}223 \\
1358\end{array}$ & $\begin{array}{r}112 \\
94\end{array}$ & $\begin{array}{l}50.2 \\
26.3\end{array}$ & $\begin{array}{r}64 \\
119\end{array}$ & $\begin{array}{l}28.7 \\
33.3\end{array}$ & $\begin{array}{r}38 \\
108\end{array}$ & $\begin{array}{l}17.0 \\
30.3\end{array}$ & $\begin{array}{r}9 \\
36\end{array}$ & $\begin{array}{r}4.0 \\
10.1\end{array}$ \\
\hline $\begin{array}{l}(105-119) \\
\text { Moderately overweight }\end{array}$ & 117 & 12 & 10.2 & 34 & 29.1 & 48 & 41.0 & 23 & 19. 7 \\
\hline (120 and more) & 19 & 0 & 0 & 3 & 15.8 & 4 & 21.0 & 12 & 63.1 \\
\hline
\end{tabular}

1 Weight for 1 adult not available. 


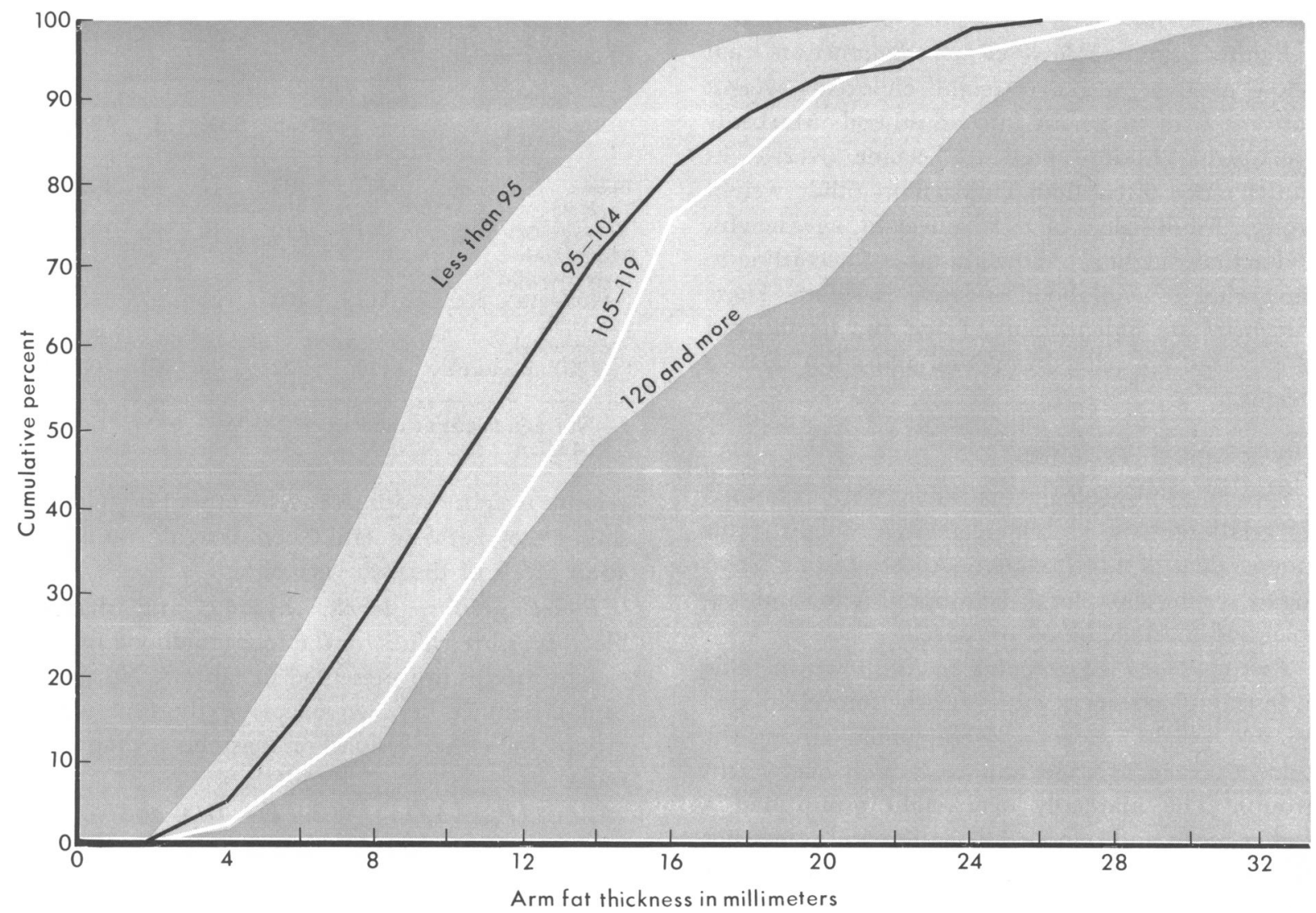

The term "overweight" is used rather than "obesity" because measurements were not available to accurately determine the amount of body fat.

We recognize that a definition of obesity based on relative weight, determined from average heightweight tables, has limitations. The definition does not describe obesity, which is defined as excess adipose tissue; rather, it describes total body weight, including fluid, bone, and muscle as well as fat.

Brozek and Keys (7) suggested that subcutaneous tissue is a more valid measure of adiposity than is weight. Figure 1 presents the cumulative frequency distributions of skinfold thickness for the four adult relative weight groups. The Lange skinfold caliper, calibrated to exert a pressure of $10 \mathrm{gm}$. per square mm. of jaw surface, was used to determine triceps skinfold measures (8). Adult classifications of the four relative weight categories show a progressive increase in skinfold thickness with increased relative weight.

A previous study by Abraham and Nordsieck (9) demonstrated that during childhood relative body weight is significantly associated with subcutaneous fat thickness. Therefore, although the term "obese" is not used to describe any portion of this study population, it may be assumed that persons within the moderately overweight category and, more specifically, those in the markedly overweight category are not only overweight but probably also obese.

The comparative disposition of the 1,963 study subjects is shown in table 2 according to childhood relative weight status. It is apparent that the segment of the population available for adult followup was remarkably similar in weight status to that not available. This suggests that the failure to locate a sizable segment of the study population is not associated with serious bias when the population is classified according to childhood relative weight.

The significance of the difference between the distribution of relative weights of those available and those unavailable was tested by using the chi-square statistic. The test indicated that the 
difference between the two groups could have arisen by chance $(0.95>P>0.90)$.

\section{Relative Weight}

Figure 2 and table 3 clearly demonstrate that below average and overweight children's weight patterns tend to persist into adulthood. Markedly overweight children tend to become overweight adults more often than children in other weight groups. Adult values of relative weight, age, height, and actual weight are shown in table 4 according to categories of childhood relative weight. These categories are independent of age and height, but as expected are related to actual and adult relative weight.

\section{Physiological Variables}

Five adult physiological variables were examined for relationship to childhood relative weight status independent of adult relative weight: fasting blood sugar, serum cholesterol, beta-lipoprotein, and systolic and diastolic blood pressure.

Fasting blood sugar values. As shown in table 5 , fasting blood sugar values for the four childhood relative weight categories were similar among the below average, average, and moderately overweight groups. The markedly overweight group had a higher mean and standard deviation and somewhat higher upper-quartile value. The $F$ test showed that the differences in mean values for the four childhood weight groups were not greater than would be expected from sampling variation: $F_{.05}(3,682)=$ 2.6, $F=0.61$. Homogeneity of variances, needed for analysis of variance, was obtained by logarithmic transformation.

Serum cholesterol and beta-lipoprotein levels. Table 6 presents levels for these two variables by childhood relative weight status. The mean values for both variables are nearly identical for the four
Table 5. Fasting blood sugar levels of male adults, by childhood weight status

\begin{tabular}{|c|c|c|c|c|c|c|}
\hline \multirow[t]{2}{*}{ Childhood weight } & \multirow{2}{*}{$\begin{array}{l}\text { Num- } \\
\text { ber } \\
\text { males }\end{array}$} & \multicolumn{2}{|c|}{$\begin{array}{l}\text { Blood sugar } \\
(\mathrm{mg} . \text { per } \\
100 \mathrm{cc} .)^{1}\end{array}$} & \multicolumn{3}{|c|}{ Quartile } \\
\hline & & Mean & S.D. & 1 & 22 & 3 \\
\hline $\begin{array}{l}\text { Below } \quad \text { average } \\
(<95)\end{array}$ & 207 & 105 & 17 & 94 & 102 & 114 \\
\hline $\begin{array}{l}\text { Average }(95-104) \\
\text { Moderately }\end{array}$ & 344 & 110 & 19 & 95 & 105 & 118 \\
\hline $\begin{array}{l}\text { overweight } \\
\text { (105-119) } \\
\text { Markedly }\end{array}$ & 113 & 108 & 20 & 97 & 105 & 115 \\
\hline $\begin{array}{l}\text { overweight } \\
\text { (120 and more) - }\end{array}$ & 19 & 122 & 45 & 101 & 108 & 123 \\
\hline
\end{tabular}

1 Not significant at the level $P>0.05$.

2 Median.

relative weight groups. It is evident that no relationship exists between childhood weight status and adult levels of the two variables.

Blood pressure levels. Systolic and diastolic blood pressure values for the four childhood relative weight groups are presented in table 7. No significant difference between means of the four weight groups for either systolic or diastolic pressure was found.

$$
\begin{gathered}
\left(F_{.05}(3,711)=3.0 F=0.06\right. \text { and } \\
\left.F_{.05}(3,711)=3.0, F=1.4\right)
\end{gathered}
$$

Blood pressure values, particularly for diastolic blood pressure, were somewhat higher at the upper quartile end of the markedly overweight group.

\section{Variables in Relation to Adult Weight}

The same adult physiological variables were then studied in relation to adult relative weight status independent of childhood relative weight. Means and standard deviations for each of the representative weight groups appear in tables 8-12. Analysis of variance test indicated a significant difference

\begin{tabular}{|c|c|c|c|c|c|c|c|c|c|c|c|c|c|}
\hline \multirow{3}{*}{ Childhood weight } & \multirow{3}{*}{$\begin{array}{c}\text { Number } \\
\text { males }\end{array}$} & \multicolumn{12}{|c|}{ Adults } \\
\hline & & \multicolumn{3}{|c|}{ Age (years) } & \multicolumn{3}{|c|}{ Height (inches) } & \multicolumn{3}{|c|}{ Weight (pounds) } & \multicolumn{3}{|c|}{ Relative weight } \\
\hline & & Mean & S.D. & Median & Mean & S.D. & Median & Mean & S.D. & Median & Mean & S.D. & Median \\
\hline \multirow{3}{*}{$\begin{array}{l}\text { Below average }(<95) \\
\text { Average }(95-104) \\
\text { Moderately over- } \\
\text { weight (105-119) } \\
\text { Markedly overweight } \\
\quad(120 \text { and more) }\end{array}$} & $\begin{array}{r}223 \\
1358\end{array}$ & $\begin{array}{l}47.5 \\
47.7\end{array}$ & $\begin{array}{l}2.5 \\
2.3\end{array}$ & $\begin{array}{l}47.3 \\
47.6\end{array}$ & $\begin{array}{l}69.1 \\
68.7\end{array}$ & $\begin{array}{l}2.4 \\
2.6\end{array}$ & $\begin{array}{l}69.3 \\
68.8\end{array}$ & $\begin{array}{l}162.6 \\
172.6\end{array}$ & $\begin{array}{l}20.3 \\
25.6\end{array}$ & $\begin{array}{l}162.4 \\
171.5\end{array}$ & $\begin{array}{r}95.2 \\
102.5\end{array}$ & $\begin{array}{l}12.5 \\
13.3\end{array}$ & $\begin{array}{r}94.9 \\
101.7\end{array}$ \\
\hline & 117 & 47.6 & 2.3 & 47.6 & 68.1 & 2.4 & 68.1 & 182.4 & 23.4 & 181.6 & 109.6 & 13.3 & 109.2 \\
\hline & 19 & 47.9 & 2.5 & 47.9 & 68.9 & 2. 1 & 68.8 & 216.6 & 38.5 & 222.5 & 124.5 & 19.8 & 125.8 \\
\hline
\end{tabular}

Table 4. Characteristics of selected male adults, by childhood weight status

1 Weight for 1 adult not available. 
Figure 2. Weight status of selected men according to childhood weight status

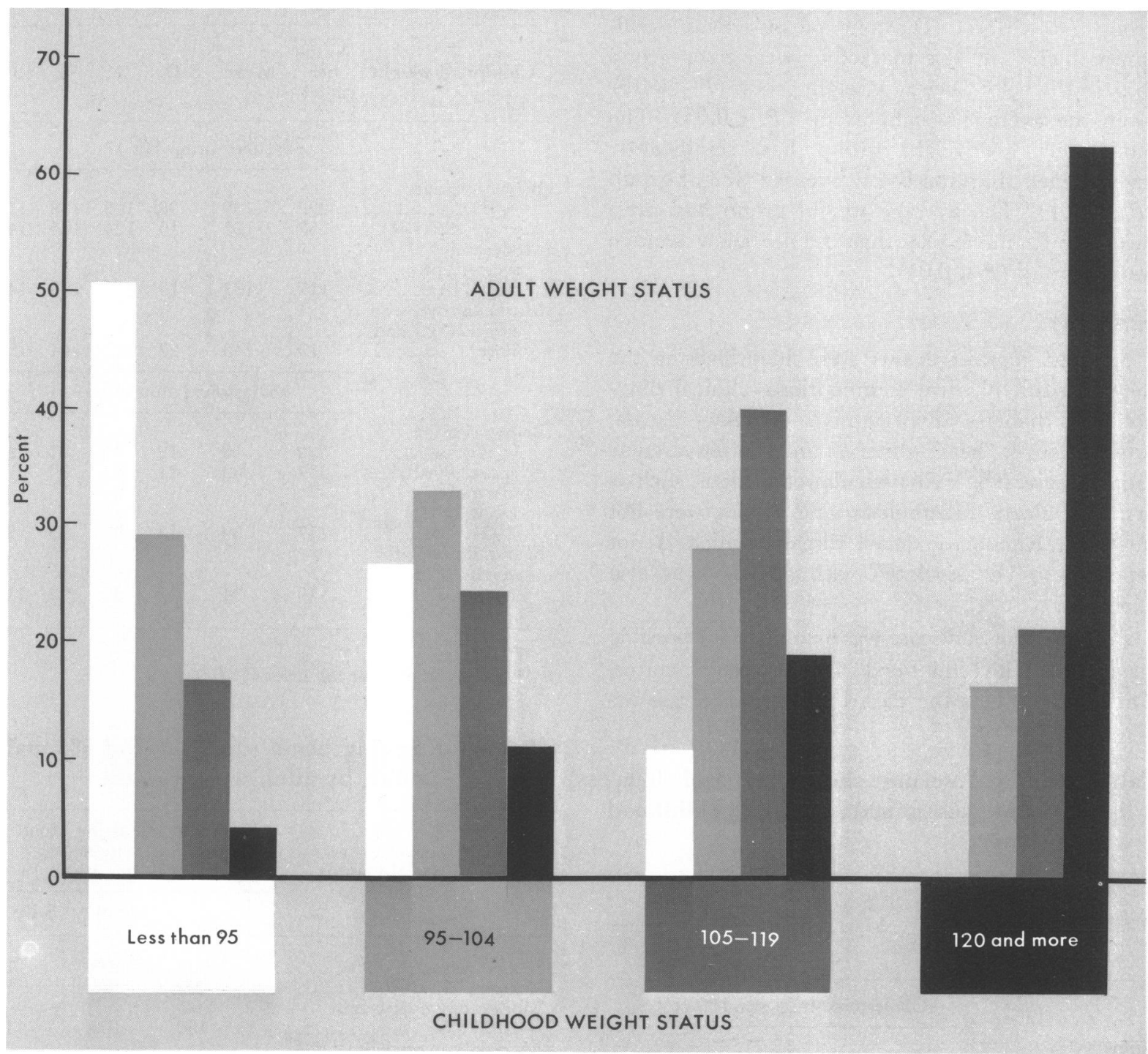

between the means for four physiological variables: fasting blood sugar $(P<0.01)$, beta-lipoprotein $(P<0.05)$, systolic blood pressure $(P<0.01)$, and diastolic blood pressure $(P<0.01)$.

For fasting blood sugar and blood pressure, homogeneity of variance was obtained by logarithmic transformation. $F$ tests permit an analysis which rejects the null hypothesis that all the means are equal, but they do not provide a procedure for comparing specific means with one another. Multiple comparison tests were used to compare combinations of means (10).

Fasting blood sugar levels. Fasting blood sugar levels by adult weight status appear in table 8 . The markedly overweight group had significantly higher values $(P<0.01)$ than did either the moderately overweight, average weight, or below average weight groups. The moderately overweight group had significantly higher values than did the below average weight group $(P<0.01)$.

Serum cholesterol and beta-lipoprotein levels. Table 9 presents values for serum cholesterol which were not significantly related to weight status. As shown in table 10, the values for beta-lipoprotein in both the moderately and the markedly overweight groups were significantly higher than in the below average weight group $(P<0.05)$.

Blood pressure levels. Adult blood pressure levels are presented in table 11. Systolic pressures in the markedly overweight group were significantly higher than in the average weight group $(P<0.05)$ and the below average weight group $(P<0.01)$. 
The moderately overweight group had values significantly higher than did the below average weight group $(P<0.05)$. Diastolic pressure was signficantly higher in the markedly overweight group than in the below average weight group $(P<0.01)$ or in the average weight group $(P<0.05)$. The moderately overweight group had significantly higher levels than the below average weight group $(P<0.01)$. The average weight group had pressures significantly higher than did the below average weight group $(P<0.01)$.

\section{Morbidity}

Selected morbid events were identified at the time of adult physical examination-clinical diagnosis of diabetes, hypertensive vascular disease, arteriosclerotic heart disease, and cardiovascular renal disease. Noncardiovascular conditions, such as arthritis, ulcers, tuberculosis, and others, were not included. Rheumatic heart disease, which is not reported to be associated with obesity, was also excluded.

Each diagnosed disease was examined for possible association with childhood relative weight status. Table 12 presents the data by prevalence rate ac-

Table 6. Total serum cholesterol and betalipoprotein levels ${ }^{1}$ of male adults, by childhood weight status

\begin{tabular}{|c|c|c|c|c|}
\hline & Num- & & & Quartile \\
\hline & males & ean & . & $\begin{array}{lll}1 & 22 & 3\end{array}$ \\
\hline
\end{tabular}

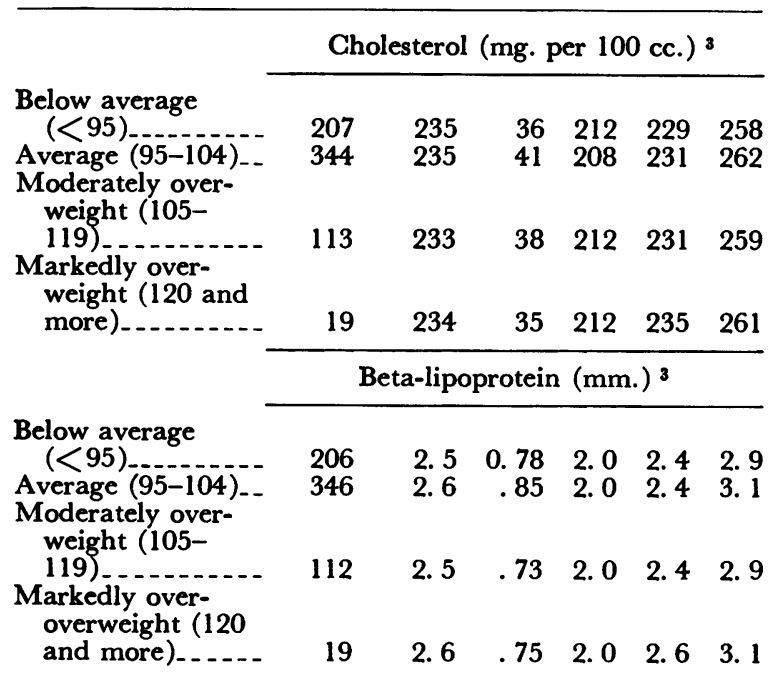

\footnotetext{
1 Determined according to immunocrit technique.

2 Median.

Not significant at the level $P>0.05$.
}

Table 7. Systolic and diastolic blood pressure of male adults, by childhood weight status

\begin{tabular}{|c|c|c|c|c|c|c|}
\hline Childhood weight & $\begin{array}{l}\text { Num- } \\
\text { ber } \\
\text { males }\end{array}$ & Mean & S.D. & 1 & 12 & 3 \\
\hline
\end{tabular}

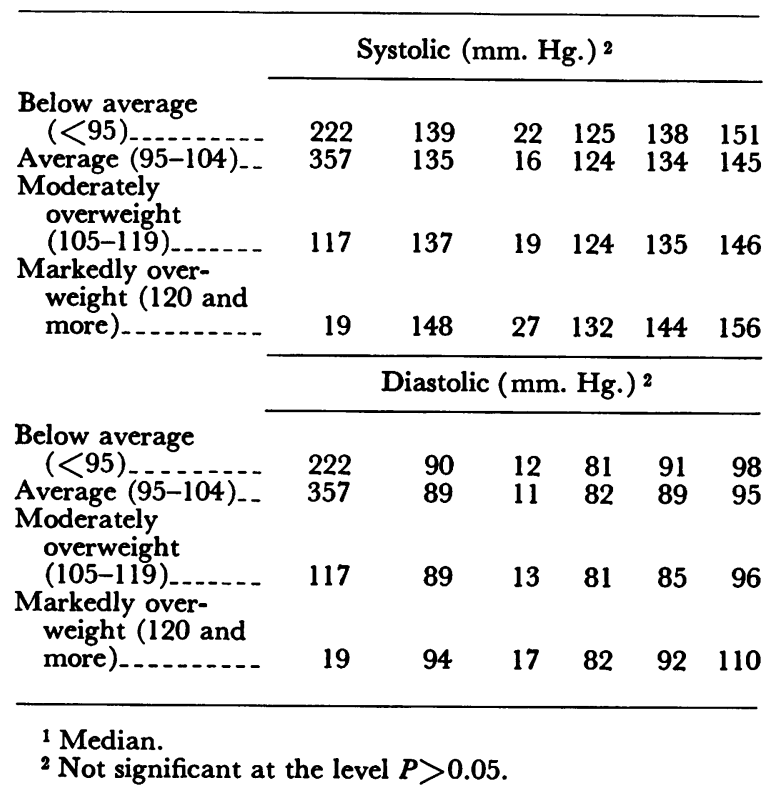

Table 8. Fasting blood sugar level of 682 male adults, by adult weight status

\begin{tabular}{lccc}
\hline & $\begin{array}{c}\text { Number } \\
\text { males }\end{array}$ & $\begin{array}{c}\text { Fasting blood } \\
\text { sugar (mg. } \\
\text { per 100cc.) }\end{array}$ \\
\cline { 2 - 4 } & & Mean & S.D. \\
\hline $\begin{array}{l}\text { Below average }(<95) \\
\text { Average }(95-104)\end{array}$ & 208 & 103 & 13 \\
$\begin{array}{c}\text { Moderately overweight } \\
(105-119)\end{array}$ & 209 & 106 & 17 \\
$\begin{array}{c}\text { Markedly overweight }(120 \\
\text { and more) }\end{array}$ & 190 & 108 & 18 \\
\hline
\end{tabular}

1 Significant at the level $P<0.01$.

cording to childhood weight categories. The prevalence rate was highest in the markedly overweight group for both diabetes and arteriosclerotic heart disease. The number of persons was too small to permit testing for significance.

Prevalence of hypertensive vascular disease was significantly related to childhood relative weight; the below average weight children had a higher prevalence than either the average weight or the moderately overweight groups.

Cardiovascular renal disease was not significantly related to childhood relative weight, but persons 
Table 9. Serum cholesterol level of 683 male adults, by adult weight status

\begin{tabular}{|c|c|c|c|}
\hline \multirow[t]{2}{*}{ Adult weight status } & \multirow{2}{*}{$\begin{array}{l}\text { Number } \\
\text { males }\end{array}$} & \multicolumn{2}{|c|}{$\begin{array}{c}\text { Cholesterol } \\
(\mathrm{mg} \cdot \text { per } 100 \mathrm{cc})^{1}\end{array}$} \\
\hline & & Mean & S.D. \\
\hline $\begin{array}{l}\text { Below average }(<95) \\
\text { Average }(95-104) \\
\text { Moderately overweight }\end{array}$ & $\begin{array}{l}209 \\
209\end{array}$ & $\begin{array}{l}232 \\
236\end{array}$ & $\begin{array}{l}38 \\
38\end{array}$ \\
\hline $\begin{array}{l}(105-119) \\
\text { Markedly overweight (120 }\end{array}$ & 190 & 239 & 41 \\
\hline and more) & 75 & 231 & 39 \\
\hline
\end{tabular}

1 Not significant at the level $P>0.05$.

who were markedly overweight as children showed the highest prevalence.

The same adult morbid events were examined for relationships to adult relative weight. Table 13 presents the diagnosis by adult weight status, with the chi-square test of significance indicating that adult relative weight status was significantly related to hypertensive vascular disease and cardiovascular renal disease. Diabetes was directly related to adult weight, showing increase in prevalence rate with increase in weight status. The markedly overweight adult group showed the highest prevalence rate. Small sample sizes did not permit a chi-square test of significance.

Hypertensive vascular disease. Hypertensive vascular disease was significantly higher in the markedly overweight group than in the below average weight group $(P<0.01)$ as it was in the average weight $(P<0.05)$ and the moderately overweight $(P<0.025)$. The higher prevalence in the markedly overweight group, as contrasted to the average and moderately overweight groups, was not statistically significant.

Cardiovascular disease. Cardiovascular renal disease was significantly higher in the markedly overweight group than in the below average weight $(P<0.01)$. The increase in prevalence in the markedly overweight group over that observed in the average and moderately overweight groups was not statistically significant.

\section{Morbidity in Relation to Weight}

Because certain morbid events were related only to adult relative weight and others to both adult and childhood relative weight, the data were examined to determine if such relationships were independent. For this analysis, the adult relative weights were arrayed into the previously defined four weight categories. The childhood weights were arrayed into three weight categories, with the mod- erately and markedly overweight groups merged because of the small number of subjects in the latter group.

Diabetes. Adult relative weight was related to diabetes, with prevalence increases appearing with each increase in weight category. A somewhat similar trend appeared with childhood relative weight, but the number was too small to permit testing; therefore, no association between childhood and adult weight could be examined.

Atherosclerosis. Atherosclerosis was not significantly related to adult relative weight; the number of subjects was too small to permit testing in childhood groups.

Hypertensive vascular disease. Table 14 and figure 3 present the prevalence rates for hypertensive vascular disease in relation to childhood weight status and subsequent adult weight status. The highest rates were noted among overweight adults who were below average weight children, with rates increasing with each increase in adult weight category.

Table 10. Beta-lipoprotein level ${ }^{1}$ of 680 male adults, by adult weight status

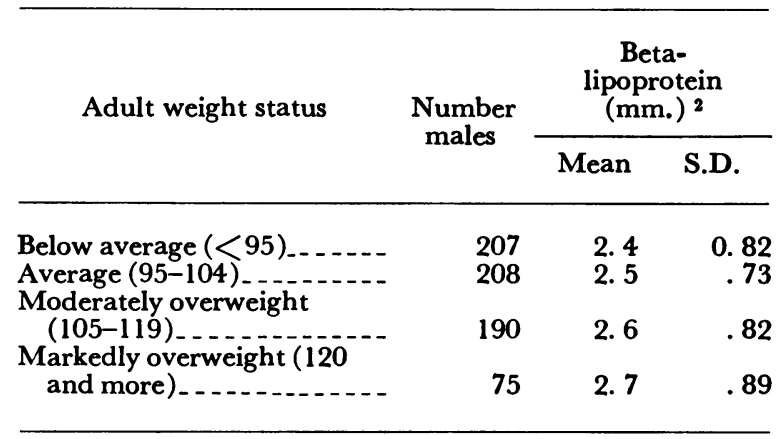

1 Determined according to immunocrit technique.

2 Significant at the level $P<0.05$.

Table 11. Blood pressure level of 714 male adults, by adult weight status

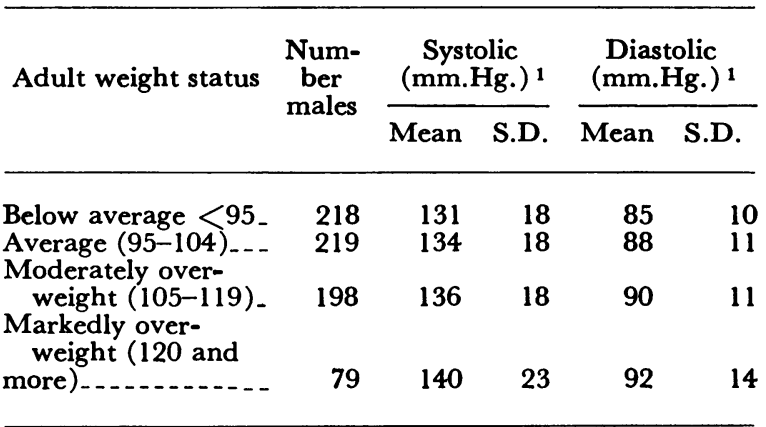

1 Significant at the level $P<0.01$. 
Cardiovascular renal disease. Table 14 and figure 4 present the prevalence rates for cardiovascular renal disease in relation to childhood weight status and subsequent adult weight status. Somewhat similar rate levels were observed for hypertensive vascular disease. The highest rates were also noted among overweight adults who were below average weight children, with rates increasing with each increase in adult weight category.

Another approach to analysis is to group the data into three patterns of change in relative weight status which occurred from childhood to adulthood: stable or no change, decrease, or increase. Table 15 shows the prevalence rates for hypertensive vascular disease and cardiovascular renal disease arrayed by this method. The rates were highest when adult weights increased to overweight status, an increase of two or more weight categories from the childhood baseline weight. The lowest rates were indicated when both the adult and childhood weight patterns were stable or showed no change in weight category, and also when the adult weights decreased to average weight or less from childhood weights.

An exception to the pattern was the adult group that showed an increase in one weight category from childhood and a recorded low rate of hypertensive and cardiovascular renal diseases.

\section{Discussion}

The relationship of childhood weight status to adult levels of blood pressure, serum cholesterol, beta-lipoprotein, and fasting blood sugar had important implications because the presence of elevations of these variables is associated with diagnosis of cardiovascular disorders and diabetes. Thus, if childhood weight status, either independently or through some association with subsequent adult weight status, manifests an association with abnormalities of the physiological variables or with diagnosed cardiovascular renal disease or diabetes,

Table 12. Diagnosed diseases among selected male adults, by childhood weight status

\begin{tabular}{|c|c|c|c|c|c|c|c|c|c|}
\hline \multirow{3}{*}{ Diagnosis } & \multicolumn{8}{|c|}{ Childhood weight status } & \multirow{3}{*}{$\begin{array}{c}\text { Chi- } \\
\text { square } \\
(\mathrm{df}=3)\end{array}$} \\
\hline & \multicolumn{2}{|c|}{$\left.\begin{array}{c}<95 \\
(\mathrm{~N}\end{array}=222\right)$} & \multicolumn{2}{|c|}{$\begin{array}{c}95-104 \\
(\mathrm{~N}=358)\end{array}$} & \multicolumn{2}{|c|}{$\begin{array}{c}105-119 \\
(\mathrm{~N}=117)\end{array}$} & \multicolumn{2}{|c|}{$\begin{array}{l}120 \text { and more } \\
(N=19)\end{array}$} & \\
\hline & Number & Percent & Number & Percent & Number & Percent & Number & Percent & \\
\hline $\begin{array}{l}\text { Diabetes }(260) \\
\text { Ar teriosclerotic heart disease }\end{array}$ & 7 & 3.2 & 5 & 1.4 & 3 & 2. 6 & 2 & 10.5 & (1) \\
\hline $\begin{array}{l}(420) \\
\text { Hypertensive vascular disease }\end{array}$ & 8 & 3.6 & 17 & 4. 7 & 7 & 6.0 & 2 & 10.5 & (1) \\
\hline $\begin{array}{l}\text { Cardiovascular renal disease } \\
\quad(330-334,403-409,417-468\end{array}$ & 67 & 30.2 & 81 & 22. 6 & 21 & 17. 9 & 7 & 36.8 & 28. 77 \\
\hline $592-594)$ & 97 & 43. 7 & 141 & 39.4 & 40 & 34.2 & 11 & 57. 9 & 5.38 \\
\hline
\end{tabular}

1 Insufficient data to calculate chi-square.

2 Significant at the level $P<0.05$.

Note: Numbers in parentheses are from the International
Statistical Classification of Diseases, Injuries, and Causes of Death, seventh revision, 1955.

Table 13. Diagnosed diseases among selected male adults, by adult weight status

\begin{tabular}{|c|c|c|c|c|c|c|c|c|c|}
\hline \multirow{3}{*}{ Diagnosis } & \multicolumn{8}{|c|}{ Adult weight status } & \multirow{3}{*}{$\begin{array}{l}\text { Chi- } \\
\text { square } \\
(\mathrm{df}=3)\end{array}$} \\
\hline & \multicolumn{2}{|c|}{$\begin{array}{c}<95 \\
(\mathrm{~N}=218)\end{array}$} & \multicolumn{2}{|c|}{$\begin{array}{c}95-104 \\
(\mathrm{~N}=220)\end{array}$} & \multicolumn{2}{|c|}{$\begin{array}{r}105-119 \\
(N=198)\end{array}$} & \multicolumn{2}{|c|}{$\begin{array}{l}120 \text { and more } \\
(N=79)\end{array}$} & \\
\hline & Number & Percent & Number & Percent & Number & Percent & Number & Percent & \\
\hline $\begin{array}{l}\text { Diabetes }(260) \\
\text { Arteriosclerotic heart disease }\end{array}$ & 2 & 0.9 & 3 & 1.4 & 6 & 3.0 & 6 & 7. 6 & (1) \\
\hline Hypertensive vascular disease & 5 & 2.3 & 12 & 5.5 & 11 & 5.6 & 6 & 7.6 & 4. 79 \\
\hline $\begin{array}{l}\text { Cardiovascular renal disease } \\
\quad(330-334,403-409,417-468\end{array}$ & 38 & 17. 4 & 57 & 25. 9 & 54 & 27.3 & 26 & 32.9 & 210.03 \\
\hline $592-594)$ & 74 & 33.9 & 93 & 42.3 & 80 & 40.4 & 41 & 51.9 & 28.45 \\
\hline
\end{tabular}

1 Insufficient data to calculate chi-square.

2 Significant at the level $P<0.05$.

NoTE: Numbers in parentheses are from the International
Statistical Classification of Diseases, Injuries, and Causes of Death, seventh revision, 1955. 
Figure 3. Prevalence of hypertensive vascular disease according to childhood and adult weight status

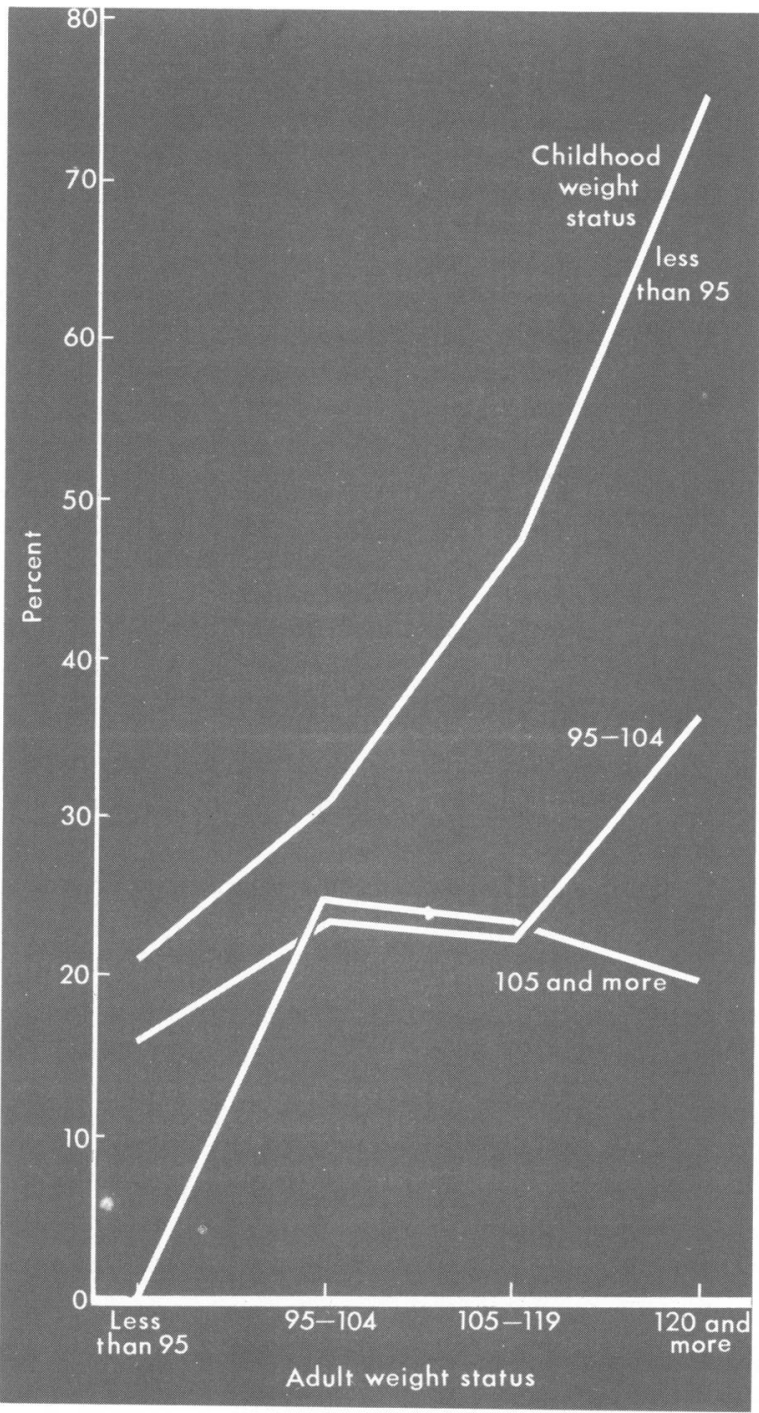

there appears to be strong support for early identification of candidates for preventive measures.

The data in table 3 and figure 1 reveal a definite pattern with reference to subsequent adult weight status based on childhood weight. Approximately 50 percent of the below average weight children were in either the adult average or overweight categories. Average weight children showed a similar tendency, with 40 percent moving into adult overweight categories. Among the moderately overweight childhood group, 60 percent remained overweight adults, and 84 percent of the markedly overweight children remained overweight as adults.
Figure 4. Prevalence of cardiovascular renal disease according to childhood and adult weight status

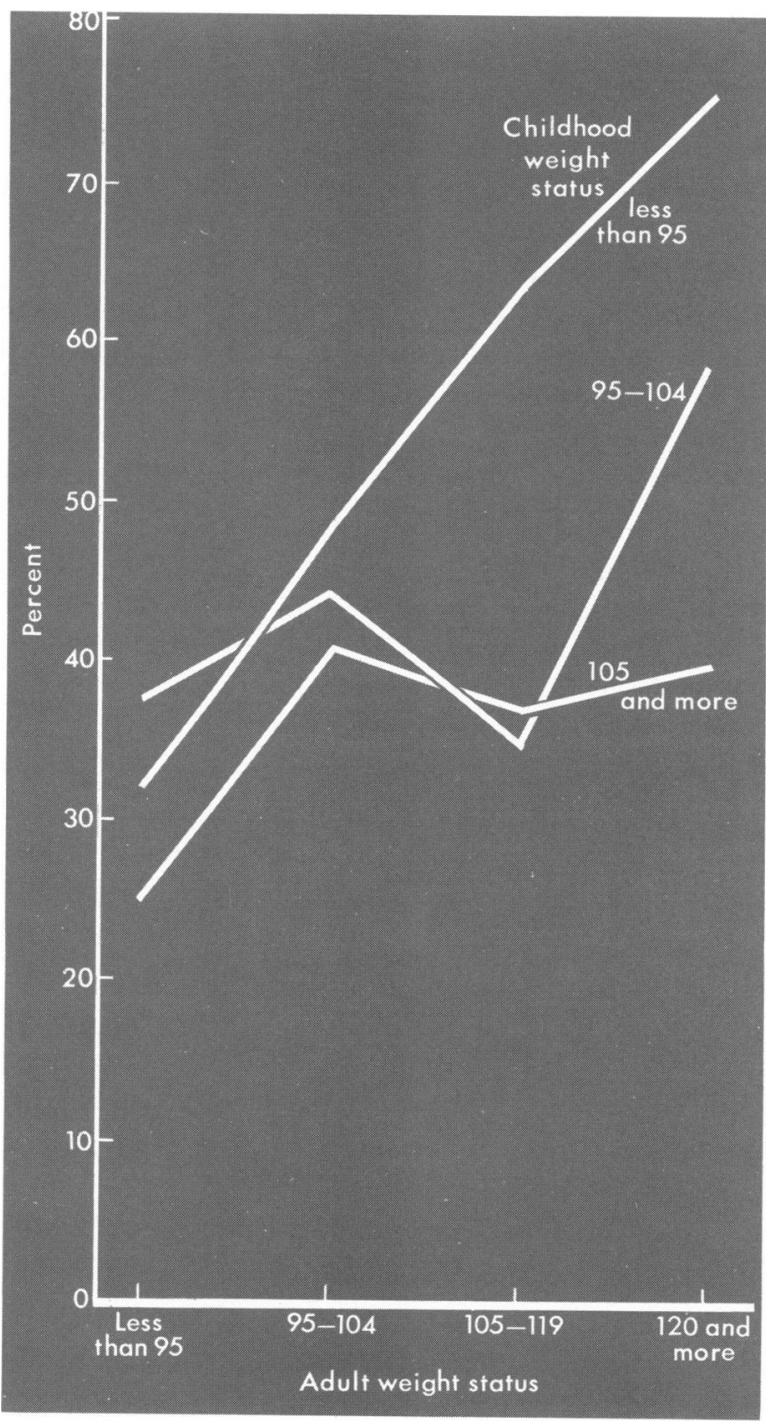

Published data have been fairly consistent in reporting the lack of success in achieving sustained weight reduction in adults (11-14). The patterns observed in this study, that is, for below average and average weight children to move upward in adult weight status and for overweight children, particularly those markedly so, to remain overweight as adults, strongly reinforce the cause for prevention of overweight.

The data for association between the selected physiological variables and childhood weight status alone revealed no statistically significant relationships. With reference to diagnoses, a significantly 
higher prevalence of hypertensive vascular disease was associated with the below average weight childhood group over that noted in either the average or moderately overweight childhood groups (table 12).

The presence of a statistically significant relationship between blood pressure, beta-lipoprotein, fasting blood sugar, hypertensive vascular disease, and cardiovascular renal disease with adult overweight status and observed upward mobility from childhood weight status posed the question: "Is the total overweight adult group at risk, or some particular segment?" Or, as expressed by Albrink and Meigs (15), were we observing two kinds of "fat" men-the fat "fat" men, who have been fat all their lives, and the fat "thin" men, who gained during adult life?

Our weight data are based on two periods: childhood, ages 9-13, and adulthood, average age 48. Thus, it is not possible to state at what age increased weight status occurred; however, it is assumed that the gains increased with increasing age in adulthood. The years following our childhood age group (post pubertal) are generally characterized by either no change in weight status or a loss of prepubertal weight gain. Insurance data indicate that after age 20 , with increasing height each 10 -year age-span shows an increase in average weight, leveling off at ages 60-69 (6). The weight pattern is also evident in the Health Examination Survey findings of the National Center for Health Statistics. However, the leveling off is at an earlier age $(16)$.

Thus, the data may be considered consistent with observations of Albrink and Meigs (15) that " 'ac-
Table 14. Prevalence of hypertensive vascular disease (HVD) and cardiovascular renal (CVR) disease, by adult relative weight and childhood relative weight

\begin{tabular}{|c|c|c|c|c|}
\hline \multirow{2}{*}{$\begin{array}{l}\text { Adult } \\
\text { relative } \\
\text { weight }\end{array}$} & \multirow{2}{*}{$\begin{array}{l}\text { Childhood } \\
\text { relative } \\
\text { weight }\end{array}$} & \multirow{2}{*}{$\begin{array}{l}\text { Number } \\
\text { of } \\
\text { subjects }\end{array}$} & \multicolumn{2}{|c|}{ Percent } \\
\hline & & & HVD & CVR \\
\hline 9 & $\left\{\begin{array}{l}<95-104 \\
105 \text { and more }\end{array}\right.$ & $\begin{array}{r}112 \\
94 \\
12\end{array}$ & $\begin{array}{r}20.5 \\
16.0 \\
0.0\end{array}$ & \\
\hline $95-1$ & $\left\{\begin{array}{l}<95 \\
9504 \text { and more }\end{array}\right.$ & $\begin{array}{r}64 \\
119 \\
37\end{array}$ & $\begin{array}{l}31.3 \\
23.5 \\
24.3\end{array}$ & $\begin{array}{l}48 \\
39 \\
40\end{array}$ \\
\hline 105-119 & $\left\{\begin{array}{l}<95 \\
95-104 \\
105 \text { and more. }\end{array}\right.$ & $\begin{array}{r}38 \\
108 \\
52\end{array}$ & $\begin{array}{l}47.4 \\
22.2 \\
23.1\end{array}$ & $\begin{array}{l}34 \\
36 .\end{array}$ \\
\hline $\begin{array}{l}120 \text { and } \\
\text { more. }\end{array}$ & $\left\{\begin{array}{l}<95 \\
95-104 \\
105 \text { and more }\end{array}\right.$ & $\begin{array}{r}8 \\
36 \\
35\end{array}$ & $\begin{array}{l}75.0 \\
36.1 \\
20.0\end{array}$ & $\begin{array}{l}75 . \\
58 . \\
40 .\end{array}$ \\
\hline
\end{tabular}

quired' obesity, attained after maturity, even though moderate in degree, might be different from 'natural' (lifelong) obesity ..." with reference to the associations in this study found with hypertensive vascular disease and cardiovascular renal disease.

Despite a higher prevalence rate of hypertensive vascular disease in both the moderate and markedly overweight adult groups (fig. 3), this was principally attributable to subjects within those groups who had been below average weight children. Among the average weight adults, the highest prevalence of hypertensive vascular disease occurred among those who had been below average weight children. Adults who were overweight as both children and adults experienced prevalence rates for

Table 15. Prevalence of hypertensive vascular disease (HVD) and cardiovascular renal (CVR) disease, by relative weight pattern changes from childhood to adulthood

\begin{tabular}{|c|c|c|c|c|c|}
\hline \multirow{2}{*}{$\begin{array}{l}\text { Relative weight } \\
\text { status }\end{array}$} & \multirow{2}{*}{$\begin{array}{l}\text { Childhood } \\
\text { relative } \\
\text { weight }\end{array}$} & \multirow{2}{*}{$\begin{array}{l}\text { Adult relative } \\
\text { weight }\end{array}$} & \multirow{2}{*}{$\begin{array}{l}\text { Number of } \\
\text { subjects }\end{array}$} & \multicolumn{2}{|c|}{ Percent } \\
\hline & & & & HVD & GVR \\
\hline $\begin{array}{c}\text { Stable or no } \\
\text { change }\end{array}$ & $\left\{\begin{array}{l}95 \\
105 \text { and more } \\
105 \text { and more }\end{array}\right.$ & $\begin{array}{l}<95 \\
105-119 \\
120 \text { and more. }\end{array}$ & $\begin{array}{r}112 \\
119 \\
52 \\
35\end{array}$ & $\begin{array}{l}20.5 \\
23.5 \\
23.1 \\
20.0\end{array}$ & $\begin{array}{l}32.1 \\
39.5 \\
36.5 \\
40.0\end{array}$ \\
\hline $\begin{array}{l}\text { Decrease: } \\
\text { 1 } \\
\text { Increase: }\end{array}$ & $\begin{array}{l}95-104 \\
105 \text { and more } \\
105 \text { and more. }\end{array}$ & $\begin{array}{l}<95 \\
95-104\end{array}$ & $\begin{array}{l}94 \\
37 \\
12\end{array}$ & $\begin{array}{r}16.0 \\
24.3 \\
0.0\end{array}$ & $\begin{array}{l}37.2 \\
40.5 \\
25.0\end{array}$ \\
\hline $\begin{array}{l}\text { lease: } \\
1 \\
1 \\
1 \\
3 \\
4\end{array}$ & $\begin{array}{l}95-104 \\
<95 \\
<95 \\
<95\end{array}$ & $\begin{array}{l}105-119 \\
95-104-119 \\
120 \text { and more. } \\
120 \text { and more. }\end{array}$ & $\begin{array}{r}108 \\
64 \\
38 \\
36 \\
8\end{array}$ & $\begin{array}{l}22.2 \\
31.3 \\
47.4 \\
36.1 \\
75.0\end{array}$ & $\begin{array}{l}34.3 \\
48.4 \\
63.2 \\
58.3 \\
75.0\end{array}$ \\
\hline
\end{tabular}


hypertensive vascular disease comparable to adults who were average weight as both children and adults.

The associations that this study has shown between childhood weight status, adult weight status, selected physiological variables, and morbid events have major importance. More than half the deaths in the United States each year are attributable to cardiovascular renal causes (17). The illness, curtailed activity, and of ten total disability that may accrue as residuals of cardiovascular renal disease are not only health concerns but also economic and sociological concerns.

The evidence of strong correlation between obesity and heart disease was first noted by Rogers (18) and has been strikingly corroborated by later insurance data. Despite intervening years and continuing research, the nature of the association remains unclear and reports are not always in agreement on the presence of such an association. The 20-year prospective study of coronary heart disease in Framingham, Mass., implicates "extreme" overweight, but only when associated with hypertension or hypercholesteremia, or both (2). The Albany, N.Y., study implicates the degree of obesity, with gross overweight (defined as 40 percent or more over ideal weight) quadrupling the risk, but little increase in risk of ischemic heart disease in persons of lesser degrees of overweight (3).

The findings in a 10-year prospective study in Los Angeles showed little or no effect of relative weight on rates of risk of coronary disease by type of manifestation other than that accounted for by high serum cholesterol level or elevated blood pressure (19). Relative weight in the population was based on the index of height divided by the cube root of weight.

Variations in method of assessing weight status, the almost complete lack of information on "fatness" as contrasted to total body weight, and lack of a weight history either as to childhood weight or subsequent weight changes, create serious shortcomings in any effort to clearly define an association between weight and morbidity or mortality.

Further important factors include the growing evidence that in man, as has been demonstrated in animals, a type of hereditary obesity may exist. Further knowledge about adipose tissue per se may well reveal clarifying information about cardiovascular disease.

Bjurlf (20) discussed the possibility that the association between coronary heart disease and over- weight may be due to the "type" of obesity. He pointed out that the size of fat cells varies in a person and that the size of the cells is a measure of exogenous influence (nutrition) with the number of cells reflecting an endogenous or inherited factor. He also indicated that fat cell size (from three various body sites) is significantly correlated with atherosclerosis, indicating that "acquired" obesity is the type involved.

The Hagerstown study presented an opportunity to examine childhood weight and subsequent changes in adult weight status in relation to cardiovascular abnormalities and diabetes. The results emphasize the urgent need for early identification of the pre-obese person and the co-existing need for well-defined preventive measures.

The study demonstrated that prevalence rates for hypertensive vascular and cardiovascular renal disease varied within the average, moderately overweight, and markedly overweight adult groups, and that the adult who had been a below average weight child had the highest rate in each of these respective categories, which may well be a function of adult acquired "fatness." The average weight adult, who was a below average weight child, may, in fact, have more "fat" than the overweight adult who was also an overweight child. These findings reemphasize the pressing need for some valid measure of body fatness that may be used in epidemiologic studies.

\section{REFERENCES}

(1) Marks, H. H.: Influence of obesity on morbidity and mortality. Bull N Y Acad Med 36: 296-312, May 1960.

(2) Kannel, W. B., Lemauer, E. F., Dawber, T. F., and McNamara, P. M.: Relation of body weight to development of coronary heart disease: Framingham study. Circulation 35: 734 (1967).

(3) Doyle, J. T., Heslin, A. S., Hilleboe, H. E., and Formel, P. F.: Early diagnosis of ischaemic heart disease. New Eng J Med 261: 1090 (1959).

(4) Lawrence, P. S., and Tibbitts, C.: Recent longterm morbidity studies in Hagerstown, Maryland. Methods in public health research, II. Amer J Public Health 41: 101-107, January 1951.

(5) Iowa Ghild Welfare Research Station: BaldwinWood tables. State University of Iowa, Iowa City, 1924.

(6) Society of Actuaries: Build and blood pressure study. Chicago, 1959, vol. 1.

(7) Brozek, J., and Keys, A.: The evaluation of leanness-fatness in man. Norms and interrelationships. Brit J Nutr 5: 194-206 (1951).

(8) Committee on Nutritional Anthropometry, Food and 
Nutrition Board, National Research Council (A. Keys, chairman): Recommendations concerning body measurements for the characterization of nutritional status. In Body measurements and nutrition, edited by J. Brozek. Wayne University Press, Detroit, 1956, p. 1.

(9) Abraham, S., and Nordsieck, M.: Relationship of excess weight in children and adults. Public Health Rep 75: 263-273, March 1960.

(10) Ryan, T. A.: Multiple comparisons in psychological research. Psychol Bull 1: 26-47 (1959).

(11) McCann, M., and Trulson, M. F.: Long-term effects of weight reducing programs. J Amer Diet Assoc 31: 1108-1110 (1955).

(12) Stunkard, A., and McLaren-Hume, M.: Results of treatment for obesity. A review of the literature and report of a series. Arch Intern Med (Chicago) 103: 79-85 (1959).

(13) Young, C. M., et al.: The problem of the obese patient. J Amer Diet Assoc 31: 1111-1115 (1955).

(14) Mullin, A. C.: Juvenile obesity. Arch Dis Child 33: 307-314 (1958).

(15) Albrink, M. J., and Meigs, J. W.: Interrelation- ships of skinfold thickness, serum lipids, and blood sugar in normal men. Amer J Clin Nutr 15: 255 (1964).

(16) National Center for Health Statistics: Weight by height and age of adults, United States-19601962. PHS Publication No. 1000, Series 11, No. 14. U.S. Government Printing Office, Washington, D.C., May 1966.

(17) National Office of Vital Statistics: Monthly Vital Statistics Report 10: 1, Mar. 20, 1961.

(18) Rogers, O. H.: Build as a factor influencing longevity. In Transactions of the Association of Life Insurance Medical Directors of America, 12th annual meeting, May 28 and 29, 1901.

(19) Chapman, J. M., and Massey, F. J., Jr.: The interrelationship of serum cholesterol hypertension, body weight and risk of coronary disease. Results of the first ten years' follow-up in the Los Angeles Heart Study. J Chronic Dis 17: 933 (1964).

(20) Bjurlf, P.: Atherosclerosis and body build with special reference to size and number of subcutaneous fat cells. Acta Med Scand (supp.) : 349 (1959).

ABRAHAM, SIDNEY (National Center for Health Statistics), COLLINS, GRETCHEN, and NORDSIECK, MARIE: Relationship of childhood weight status to morbidity in adults. HSMHA Health Reports, Vol. 86, March 1971, pp. 273-284.

A cohort of white males who had attended elementary schools in Hagerstown, Md., between 1923 and 1928, and whose height-weight records for those years were available, was examined during 1961-63. A study of their childhood relative weight at ages 9-13, and of their adult relative weight $35-40$ years later, was made in relation to selected physiological variables and diagnosed morbidity.

Essential findings were as follows:

Childhood relative weight at ages 9-13 had no significant relationship to adult levels of fasting blood sugar, serum cholesterol, beta-lipoprotein, or blood pressure, or to cardiovascular renal disease.

Childhood relative weight at ages 9-13 was significantly related to hypertensive vascular disease. The below average weight group experienced a higher prevalence than observed in either average or moderately overweight childhood groups.

Approximately 30 percent of the below average weight children became average weight adults and 21 percent became overweight adults. Of the average weight children, approximately 40 percent became overweight adults. Overweight children tended to remain overweight as adults.

Adult relative weight of the same cohort, viewed 35-40 years later, was significantly associated with fasting blood sugar, beta-lipoprotein, and systolic and diastolic blood pressure. Elevated levels of each of these variables occurred with greater frequency in the overweight child.

Adult relative weight was significantly associated with hypertensive vascular disease and cardiovascular renal disease; the higher prevalence occurred in the overweight adults.

The highest risk for hypertensive vascular and cardiovascular renal disease was associated with the persons who acquired their overweight status as adults. The higher prevalence of these diseases among the overweight adults was largely attributable to the adults who moved from a below average childhood weight category to an overweight adult group. The moderately or markedly overweight adult who was similarly classified as a child did not appear to be at greater risk than the average weight adult who had been an average weight child. 